\title{
The Contribution of Epistemic Curiosity and its Relevance to Science Process Skills on Biology Prospective Teacher
}

\author{
Hunaepi ${ }^{*}$, Muhammad Ikhsan², Hadi Suwono ${ }^{3}$, Sulisetijono ${ }^{3}$ \\ ${ }^{1}$ Faculty of Applied Science and Technology, Universitas Pendidikan Mandalika, Mataram 83126, Indonesia \\ ${ }^{2}$ Faculty of Sports Science and Public Health, Universitas Pendidikan Mandalika, Mataram 83126, Indonesia \\ ${ }^{3}$ Biology Education Department, Universitas Negeri Malang, Jl. Semarang No.5, Kota Malang, Jawa Timur 65145, Indonesia
}

\section{DOI: 10.29303/ippipa.v7iSpecialIssue.1070}

\section{Article Info}

Received: August 28th, 2021

Revised: November 24th, 2021

Accepted: November 27th, 2021

\begin{abstract}
The purpose of this study was to determine the contribution of epistemic curiosity (EC) to the science process skills (SPS) of prospective biology teachers. Ex post facto research design with research subjects 32 students of the third-semester biology education study program at the Mandalika University of Education. Samples were taken using the purposive sampling method. The instruments used were the State Curiosity Scale (SCS) to collect epistemic curiosity data, Student Worksheets, and the Science Process Skills rubric to collect SPS. The results showed that the magnitude of the correlation value or $\mathrm{R}$ relationship was 0.600 . From the output, the coefficient of determination (R Square) was 0.359 , this shows that EC is correlated with SPS. Meanwhile, in terms of the results of simple regression analysis, it was found that the variable $\mathrm{X}(\mathrm{EC})$ obtained the value of $\mathrm{t}$-count $=4.103>1.697 \mathrm{t}$-table and sig. $=0.000<5 \%$. This means that the $\mathrm{EC}$ variable contributes significantly to the SPS variable. The results obtained have not been able to describe the contribution of EC to each SPS indicator, so further research needs to analyze the contribution of EC to each SPS indicator.
\end{abstract}

Keywords: Epistemic Curiosity; Science Proses Skills; Biology; Teacher

Citation: Hunaepi, H., Ikhsan, M. ., Suwono, H. ., \& Sulisetijono, S. (2021). The Contribution of Epistemic Curiosity and its Relevance to Science Process Skills on Biology Prospective Teacher. Jurnal Penelitian Pendidikan IPA, 7(SpecialIssue), 112-117. https://doi.org/10.29303/jppipa.v7iSpeciallssue.1070

\section{Introduction}

Curiosity is an individual's desire to know everything in depth through observation, observation, and study. Curiosity becomes a character that has an important role in the learning process to explore the level of student enthusiasm and determine the level of understanding of the subject matter through the learning activities provided. Curiosity is important to develop because; 1) The reasoning power of students becomes active so that it is beneficial for themselves and others, 2) Students become active observers, 3) what is observed and studied always has interesting challenges for them to learn, and 4) Curiosity will eliminate student boredom to continue learning (Jannah et al., 2021).
Curiosity is an important character to be developed in learning and learning (Rowson et al., 2012). The character of curiosity is an attitude and action that always seeks to know more deeply and broadly from something that is learned, seen, and heard (Kemdiknas, 2010). (Hong et al., 2016) The individual's attitude towards an object of study is influenced by a sense of belief and evaluation of the object.

Curiosity is developed into several dimensions. (Berlyne, 1954) divides curiosity into four dimensions namely; Epistemic Curiosity (EC), perceptual curiosity (PC), specific curiosity (SC), and diverse curiosity (DC), (Mcevoy et al., 2013) Empathic curiosity, (Weible \& Zimmerman, 2016) Scientifik curiosity. 
Epistemic Curiosity (EC) encourages students to engage in learning and intellectual activities to know and understand the subject matter being taught (Berlyne, 1954; K.g. et al., 2020). This is reflected in students' actions to seek new knowledge, eliminate gaps in their understanding of a topic, and engage in intellectual activities (Biggs et al., 2001). (Litman, 2008) EC affects the learning goals that students set for themselves, and determines the level of persistence or effort made to achieve the goals that have been set, both long-term goals and short-term goals.

EC reflects the desire to get new information that motivates knowledge exploration behavior through learning activities (Eren, 2009). (Berlyne, 1954; Litman, 2012) EC is the desire to acquire new knowledge (for example, concepts, ideas, and facts) which is expected to stimulate intellectual interest (type I) or eliminate the condition of lack of information (type D). (Kang et al., 2009; von Stumm et al., 2011) defines EC as the drive to seek information and eliminate gaps in knowledge which are considered important predispositions for learning complex skills. Whereas (Metcalfe et al., 2020) defines EC as a form of attention to objects in learning to explore and solve without any compelling external need. (Subaşı, 2019) EC becomes an intrinsic motivation to study and understand the material so that it can be accepted by the mind. EC is complexly determined by a combination of cognitive, affective, and motivational. EC is a motivational driver of curiosity and experimentation that underlies intellectual development and scientific achievement (Koo \& Choi, 2010).

Previous research studies conducted by (Eren, 2009) EC students mainly in curiosity as a form of feeling lacking, significantly correlated with the achievement of mastery goals and student performance approach goals. (Huck et al., 2020) EC is very important in the early phase of learning. The results of the study (Tang \& Salmela-Aro, 2021) show that EC can improve academic achievement in terms of two types; type interest curiosity and type deprivation curiosity.

Another study conducted by Istiani and Hasanah showed different results. EC and cognitive have a weak correlation (Istiani et al., 2018). (Hasanah et al., 2021) Students with high and moderate epistemic curiosity tend to be unable to determine appropriate problemsolving strategies.

The research that has been done focuses on the study of epistemic curiosity with the achievement of goals and performance approaches. So far, studies examining the role of two types of epistemic curiosity in science process skills, and (Tang \& Salmela-Aro, 2021) specific academic achievement are still lacking and limited. The lack of studies on the contribution of epistemic curiosity to Science Process Skills is one of the reasons why one basis for assessing the contribution of epistemic curiosity in developing and improving Science Process Skills.

Science process skills are thinking skills that are able to answer the demands of learning in accordance with the principles of constructivism (Asy'ari \& Fitriani, 2017). Science process skills are one of the important skills to be developed in learning because they can help students learn science process skills or inquiry skills to solve problems (Verawati et al., 2014), foster concepts (Doyan et al., 2021), and make students active in experimenting, taking responsibility, and being confident (Asy'ari et al., 2019). (Feyzioğlu, 2009) explains that PPP is the ability to apply the steps of the scientific method to understand, apply and discover knowledge scientifically.

Science process skills are classified into two, namely basic SPS and integrated SPS. Basic SPS is a skill in learning that forms concepts that include (Observing, Classifying, Inference, Measuring, Communicating, Predicting) (Aktamış \& Yenice, 2010). Integrated SPS is a skill to solve problems, and skills to conduct experiments (Hunaepi et al., 2020; Rauf et al., 2013; Sheeba, 2013), this SPS includes; (Identify variables, formulate hypotheses, tabulate and describe data in graphs, define variables, design experiments, and conduct experiments) (Ongowo \& Indoshi, 2013; Trnova \& Trna, 2016).

Based on the description that has been presented, the purpose of this study is to describe the contribution of epistemic curiosity to its relevance to students' science process skills. SPS measured on the indicator; 1 ) Observation, 2) Formulating the problem, 3) Hypothesis, 4) Identification of variables, (SPS integration), 5) Defining variables (SPS Integration), and 6) Experimental design.

\section{Method}

This research is ex post facto research. This study uses a quantitative approach with a correlational design because the research tries to find out the relationship between the correlated variables.

The object of this research is the third-semester students of biology education, Faculty of Engineering and Applied Science, Mandalika University of Education, totaling 32 people who were taken by purposive sampling.

The instrument used in collecting epistemic curiosity data is the State Curiosity Scale (SCS) developed by (Leherissey, 1971). The alpha reliability coefficient for the 20 SCS items was found to be .82 , with a mean of 48.80 and a standard deviation of 9.39 . The instruments used to collect SPS data are Student 
Worksheets and SPS Rubrics which are designed to measure basic and integrated science process skills.

Researchers collect quantitative data, statistically analyzed to show the trend of the responses given by the target population about the phenomena discussed (Creswell, 2014). The data analyzed were in the form of questionnaire results and data on the results of science process skills. After the data is obtained and tabulated and the data is processed using the SPSS application.

\section{Result and Discussion}

This study aims to describe the contribution of Epistemic Curiosity its relevance to Science Process Skills in a descriptive analysis using a simple linear regression test. The results of the prerequisite test using the Shapiro Wilk test showed that epistemic curiosity and science process skills were normally distributed $(0.359>0.05)$ so that a simple regression test could be performed to determine the contribution of EC to SPS. Below, the results of the analysis of the relationship between EC and SPS are presented in Table 1.

Table 1. Correlation value between EC and SPS

\begin{tabular}{ccccc}
\hline Model & $\mathrm{R}$ & $\mathrm{R}$ Square & $\begin{array}{l}\text { Adjusted } \\
\text { R Square }\end{array}$ & $\begin{array}{l}\text { Std. Error of } \\
\text { the Estimate }\end{array}$ \\
\hline 1 & $.600^{\mathrm{a}}$ & .359 & .338 & 1.902 \\
\hline
\end{tabular}

The table above shows that the magnitude of the correlation value or $\mathrm{R}$ relationship is 0.600 . From the output, the coefficient of determination ( $R$ Square) is 0.359 , the contribution of EC to SPS is $35.9 \%$.

Table 2. Results of simple regression analysis of EC and SPS

\begin{tabular}{|c|c|c|c|c|c|}
\hline \multirow{2}{*}{ Model } & \multicolumn{2}{|c|}{$\begin{array}{l}\text { Unstandardized } \\
\text { Coefficients }\end{array}$} & \multirow{2}{*}{$\begin{array}{c}\text { Standardized } \\
\text { Coefficients } \\
\text { Beta }\end{array}$} & \multirow{2}{*}{$\mathrm{T}$} & \multirow{2}{*}{ Sig } \\
\hline & B & $\begin{array}{l}\text { Std. } \\
\text { Error }\end{array}$ & & & \\
\hline Const & 18.908 & 2.294 & & 8.243 & .000 \\
\hline EC & .174 & .042 & .600 & 4.103 & .000 \\
\hline
\end{tabular}

The table above shows the following simple regression equation $\mathrm{Y}=18.908=.174$. This shows that the constant value is 18.908 and the coefficient value is $X=0.174$. (if the constant value increases by one point, it will cause an increase in the SPS variable by 0.174 . Thus, it can be said that EC has a positive contribution to SPS. The results of statistical testing using SPSS on variable $X(\mathrm{EC})$ obtained the value of account = $4.103>1.697 \mathrm{ttable}$ and sig. $=0.000<5 \%$, this means that the EC variable contributes significantly to the SPS variable.

This finding indicates that epistemic curiosity has a role in improving science process skills. The effective contribution of epistemic curiosity to science process skills is 0.174 .

The results of this study are in line with the opinion outlined by (J. J. Jirout, 2020) that curiosity can encourage motivation to carry out scientific investigations through the process of scientific thinking. Scientific thinking is a knowledge-seeking activity that involves searching for information starting from asking questions, formulating hypotheses, making predictions, determining variables, making observations, collecting data, and making conclusions (Jirout \& Zimmerman, 2015). The indicators presented in scientific thinking are part of the PPP indicators used in this study.

(Veronicatama et al., 2016) stated that students who have a high curiosity about biology will study the material seriously, are interested in scientific activities, such as (Hunaepi et al., 2020) making observations and observations to collect information, find facts related to learning materials. Having an interest in these activities will provide a meaningful experience (Abdullah et al., 2015).

The existence of epistemic curiosity does not only have an impact on the development of science process skills. However, being (Mussel, 2010; Tamdogon, 2006) becomes an important variable in various fields that facilitate cognitive development and the development of academic skills. (K.g. et al., 2020) stated that epistemic curiosity can function as a monitor to measure students' intellectual abilities.

Biology education students as prospective biology teachers have become imperative to have the character of curiosity and science process skills because this ability will make it easier for them to prepare themselves as teachers. (Trnova \& Trna, 2016) stated that they not only need knowledge of conceptual understanding related to scientific activities and methods, they also need to acquire planning and teaching skills to accompany the use of scientific methods for student learning.

\section{Conclusion}

The research findings show that epistemic curiosity has a positive contribution to the science process skills of prospective biology teacher students. Although there are positive contributions. However, this study has not shown the contribution of epistemic curiosity to each science process skill. So to find out the epistemic curiosity contribution to each science process skill indicator, there needs to be a study that examines more deeply each indicator. 


\section{Acknowledgments}

The results of this study can be published because of the support from the Minister of Education and Technology through the Higher Education Cooperation Research grant program between the Mandalika Education University and the State University of Malang (Contract Number 072.a/L1/LL/UNDIKMA/2021).

\section{References}

Abdullah, C., Parris, J., Lie, R., Guzdar, A., \& Tour, E. (2015). Critical Analysis of Primary Literature in a Master's-Level Class: Effects on Self-Efficacy and Science-Process Skills. CBE-Life Sciences Education, 14(3), ar34. https://doi.org/10.1187/cbe.14-10-0180

Aktamış, H., \& Yenice, N. (2010). Determination of the science process skills and critical thinking skill levels. Procedia - Social and Behavioral Sciences, 2(2), 3282-3288. https://doi.org/10.1016/j.sbspro.2010.03.502

Asy'ari, M., \& Fitriani, H. (2017). Literatur Reviu Keterampilan Proses Sains sebagai Dasar Pengembangan Keterampilan Berpikir Tingkat Tinggi. Prisma Sains: Jurnal Pengkajian Ilmu Dan Pembelajaran Matematika Dan IPA IKIP Mataram, 5(1), 1-7. https://doi.org/10.33394/jps.v5i1.1114 [Indonesian]

Asy'ari, M., Fitriani, H., Zubaidah, S., \& Mahanal, S. (2019). The Science Process Skills of Prospective Biology Teachers in Plant Cell Material Based on Gender. International Journal of Emerging Technologies in Learning (IJET), 14, 168-178. https://doi.org/10.3991/ijet.v14i19.11208

Berlyne, D. E. (1954). A Theory Of Human Curiosity. British Journal of Psychology. General Section, 45(3), 180-191.

https://doi.org/10.1111/j.2044$\underline{\text { 8295.1954.tb01243.x }}$

Biggs, J., Kember, D., \& Leung, D. Y. (2001). The revised two-factor Study Process Questionnaire: R-SPQ2F. The British Journal of Educational Psychology, 71(Pt 1), 133-149. https://doi.org/10.1348/000709901158433

Creswell, J. W. (2014). Research design: Qualitative, quantitative, and mixed methods approaches (4th ed). SAGE Publications. Retrieved from: https://us.sagepub.com/en-us/nam/researchdesign/book 255675

Doyan, A., Susilawati, S., \& Hardiyansyah, H. (2021). Development of Natural Science Learning Tools with Guided Inquiry Model Assisted by Real Media to Improve Students' Scientific Creativity and Science Process Skills. Jurnal Penelitian
Pendidikan IPA, 7(1), 15-20.

https://doi.org/10.29303/jppipa.v7i1.485

Eren, A. (2009). Examining the Relationship between Epistemic Curiosity and Achievement Goals. Eurasian Journal of Educational Research (EJER), 9, 129-144.

Feyzioğlu, B. (2009). An Investigation of the Relationship between Science Process Skills with Efficient Laboratory Use and Science Achievement in Chemistry Education. Journal of Turkish Science Education, 6(3), 114-132. Retrieved from:

https://www.tused.org/index.php/tused/articl e/view/132

Hasanah, N., Asih, T. S. N., \& Kharisudin, I. (2021). Mathematical Problem Solving Skill Viewed from Epistemic Curiosity on Fostering Communities of Learners. Unnes Journal of Mathematics Education Research, 10(A), 134-139. Retrieved from: https://journal.unnes.ac.id/sju/index.php/ujm er/article/view/35270

Hong, J.-C., Hwang, M.-Y., Szeto, E., Tai, K.-H., \& Tsai, C.-R. (2016). Positive Affect Relevant to Epistemic Curiosity to Reflect Continuance Intention to Join a Hands-On Making Contest. EURASIA Journal of Mathematics, Science and Technology Education, 12(9). https://doi.org/10.12973/eurasia.2016.1276a

Huck, J. T., Day, E. A., Lin, L., Jorgensen, A. G., Westlin, J., \& Hardy, J. H. (2020). The Role of Epistemic Curiosity in Game-Based Learning: Distinguishing Skill Acquisition From Adaptation. Simulation \& Gaming, 51(2), 141-166. https://doi.org/10.1177/1046878119895557

Hunaepi, H., Susantini, E., Firdaus, L., Samsuri, T., \& Raharjo, R. (2020). Analisis Keterampilan Proses Sains (KPS) Mahasiswa Melalui Kegiatan Praktikum Ekologi. EDUSAINS, 12(1), 98-105. https://doi.org/10.15408/es.v12i1.13869 [Indonesian]

Istiani, F., Bintari, S. H., \& Widiatningrum, T. (2018). Correlation of Epistemic Curiosity and Cognitive Understanding Biologyâ $€^{\mathrm{TM}_{S}}$ Student in Health and Pharmaceutical Biotechnology. Journal of Biology Education, 7(1), 99-107. https://doi.org/10.15294/jbe.v7i1.22553

Jannah, F., Fadly, W., \& Aristiawan, A. (2021). Analisis Karakter Rasa Ingin Tahu Siswa Pada Tema Struktur dan Fungsi Tumbuhan. Jurnal Tadris IPA Indonesia, 1(1), 1-16. Retrieved from: https://ejournal.iainponorogo.ac.id/index.php/i tii/article/view/63 [Indonesian] 
Jirout, J. J. (2020). Supporting Early Scientific Thinking through Curiosity. Frontiers in Psychology, 11, 1717. https://doi.org/10.3389/fpsyg.2020.01717

Jirout, J., \& Zimmerman, C. (2015). Development of Science Process Skills in the Early Childhood Years. In K. Cabe Trundle \& M. Saçkes (Eds.), Research in Early Childhood Science Education (pp. 143-165). Springer Netherlands. https://doi.org/10.1007/978-94-017-9505-0_7

Kang, M. J., Hsu, M., Krajbich, I. M., Loewenstein, G., McClure, S. M., Wang, J. T., \& Camerer, C. F. (2009). The Wick in the Candle of Learning: Epistemic Curiosity Activates Reward Circuitry and Enhances Memory. Psychological Science, 20(8), 963-973. https://doi.org/10.1111/j.14679280.2009.02402.x

K.g., B., V.s., V., M.m., A., C.v., A., Bhat, S., \& D'Souza, R. (2020). Influence of Epistemic Curiosity on the Study Approaches of First Year Engineering Students. Procedia Computer Science, 172, 443-451. https:// doi.org/10.1016/j.procs.2020.05.097

Koo, D.-M., \& Choi, Y.-Y. (2010). Knowledge search and people with high epistemic curiosity. Computers in Human Behavior, 26(1), 12-22. https://doi.org/10.1016/j.chb.2009.08.013

Leherissey, B. L. (1971). The Development of a Measure of State Epistemic Curiosity. Undefined. https://www.semanticscholar.org/paper/...baf

Litman, J. A. (2008). Interest and deprivation factors of epistemic curiosity. Personality and Individual Differences, 44(7), 1585-1595. https://doi.org/10.1016/j.paid.2008.01.014

Litman, J. A. (2012). Epistemic Curiosity. In N. M. Seel (Ed.), Encyclopedia of the Sciences of Learning (pp. 1162-1165). Springer US. https://doi.org/10.1007/978-1-4419-1428-6_1645

Mcevoy, P., Baker, D., Plant, R., Hylton, K., \& Mansell, W. (2013). Empathic curiosity: Resolving goal conflicts that generate emotional distress: Empathic curiosity. Journal of Psychiatric and Mental Health Nursing, 20(3), 273-278. https://doi.org/10.1111/j.13652850.2012.01926.x

Metcalfe, J., Schwartz, B. L., \& Eich, T. S. (2020). Epistemic curiosity and the region of proximal learning. Current Opinion in Behavioral Sciences, 35 , $40-47$. https://doi.org/10.1016/j.cobeha.2020.06.007

Mussel, P. (2010). Epistemic curiosity and related constructs: Lacking evidence of discriminant validity. Personality and Individual Differences, 49. https://doi.org/10.1016/j.paid.2010.05.014

Ongowo, R. O., \& Indoshi, F. C. (2013). Science Process Skills in the Kenya Certificate of Secondary Education Biology Practical Examinations.
Creative Education, 4(11), 713-717. https://doi.org/10.4236/ce.2013.411101

Rauf, R. A. A., Rasul, M. S., Mansor, A. N., Othman, Z., \& Lyndon, N. (2013). Inculcation of Science Process Skills in a Science Classroom. Asian Social Science, 9(8), p47. https://doi.org/10.5539/ass.v9n8p47

Rowson, J., Young, J., Spencer, N., Lindley, E., \& Gecius, E. (2012). The Power Of Curiosity How Linking Inquisitiveness To Innovation Could Help To Address Our Energy Challenges. RSA Social Brain Centre.

https://www.thersa.org/globalassets/pdfs/...cu riosity.pdf

Sheeba, M. N. (2013). An Anatomy of Science Process Skills In The Light Of The Challenges to Realize Science Instruction Leading To Global Excellence in Education. Undefined. https://www.semanticscholar.org/paper/...445

Subaşı, A. (2019). A Dynamic Systems Theory of epistemic curiosity. New Ideas in Psychology, 54, 8-14.

https://doi.org/10.1016/j.newideapsych.2018.12 .003

Tamdogon, O. G. (2006). Creativity in education: Clearness in perception, vigorousness in curiosity. Education for Information, 24(2-3), 139151.

Tang, X., \& Salmela-Aro, K. (2021). The prospective role of epistemic curiosity in national standardized test performance. Learning and Individual Differences, $\quad 88, \quad 102008$. https://doi.org/10.1016/j.lindif.2021.102008

Trnova, E., \& Trna, J. (2016). Science Experimental Skills under Development. 1-8. Retrieved from: https://www.researchgate.net/publication/274 $\underline{132579 \ldots . . . D e v e l o p m e n t}$

Verawati, N. N. S. V., Prayogi, S., \& Asy'ari, M. (2014). Reviu Literatur Tentang Keterampilan Proses Sains. Lensa: Jurnal Kependidikan Fisika, 2(1), 194198. $\quad \underline{\text { https://doi.org/10.33394/j-1kf.v2i1.310 }}$ [Indonesian]

Veronicatama, R. R. A., Ramli, M., Sari, D. P., \& Astorini, S. (2016). Penerapan Model Pembelajaran Inkuiri Untuk Meningkatkan Rasa Ingin Tahu Siswa Pada Materi Sistem Reproduksi Kelas XI Mia 8 SMA Negeri 1 Karanganyar Tahun Pelajaran 2014/2015. BIOPEDAGOGI, 5(2), 26-30. https://doi.org/10.20961/biopedagogi.v5i2.5422 [Indonesian]

von Stumm, S., Hell, B., \& Chamorro-Premuzic, T. (2011). The Hungry Mind: Intellectual Curiosity Is the Third Pillar of Academic Performance. 
Perspectives on Psychological Science, 6(6), 574-588. https://doi.org/10.1177/1745691611421204

Weible, J. L., \& Zimmerman, H. T. (2016). Science curiosity in learning environments: Developing an attitudinal scale for research in schools, homes, museums, and the community. International Journal of Science Education, 38(8), 1235-1255.

https://doi.org/10.1080/09500693.2016.1186853 